\title{
Histoire d'amour
}

Histoire d'amour

Tu t'en vas

Feuille orange dans la brume

Comme tu étais belle un jour

On croyait l'été à jamais durable

Les cerises, 1'abondance,

L'épervier planait au-dessus de nos têtes

On échangeait des bises

Au loin le Mont Blanc, criant sa blancheur

Piano, piano, on se suivait, la musique

D'en bas nous grisait.

Dans les champs les enfants se submergeaient en violet.

1982

KENNETH S. WHITE

THE UNIVERSITY OF KANSAS 


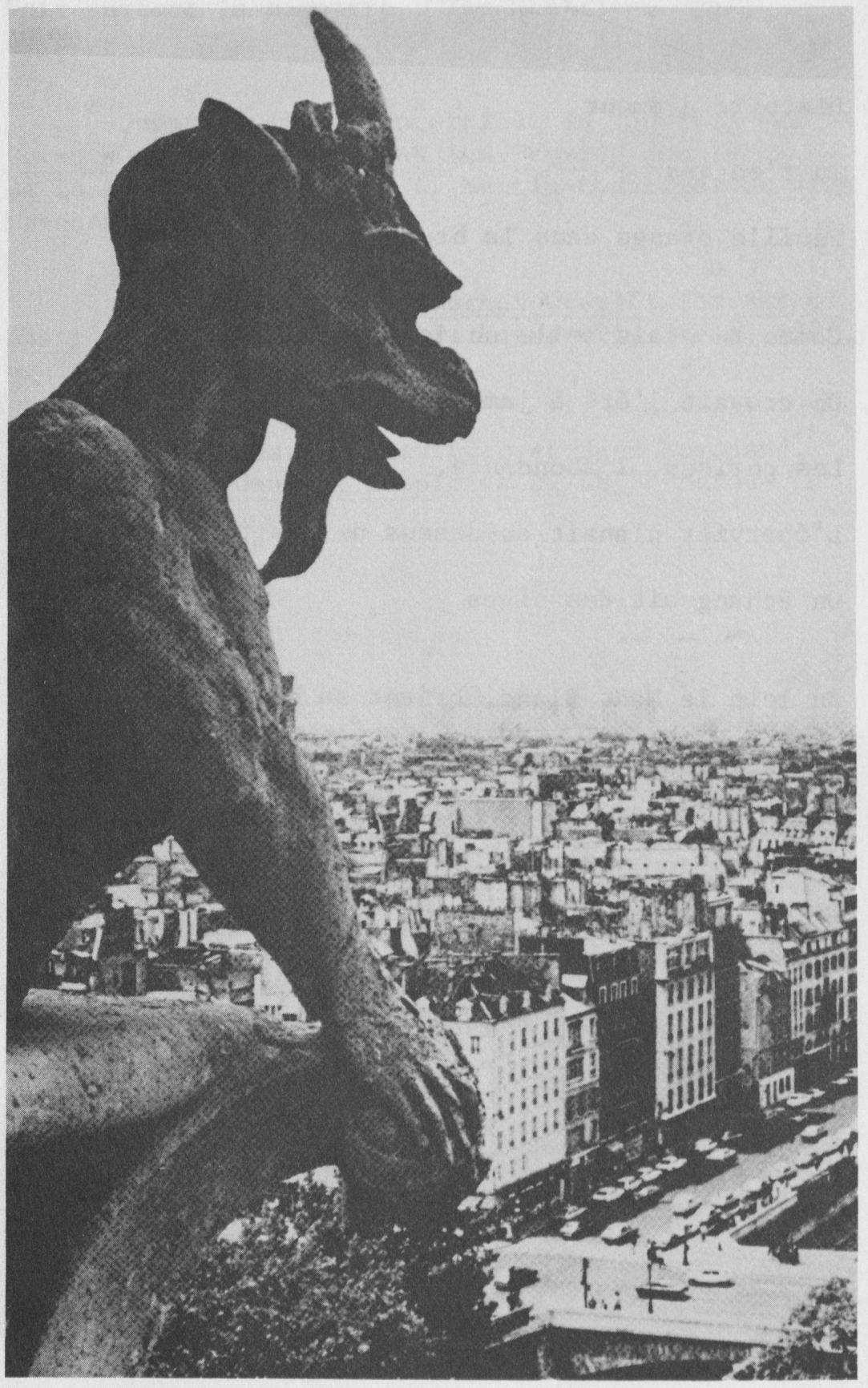

